\title{
シート状プラスチック粒子の連続静電分離
}

\section{The Continuous Triboelectric Separation for Plastic Sheets}

\author{
竹下 武成, 原田 敏宏, 武市 誠治, 齋藤 孝博 \\ Takenari TAKESHITA, Toshihiro HARADA, Seiji TAKEICHI, Takahiro SAITO
}

\begin{abstract}
An apparatus for continuously separating specific plastic from plastic mixtures was devised. The apparatus consisted of a triboelectric section and an electrostatic separating section according to their polarities. Various plastic sheets were frictionally electrified in the first fluidized bed and then introduced into the second fluidized bed where plastic sheets were blown off into the electrostatic separation unit. The recovery of plastics was more than $70 \%$ for polyvinyl chloride, and $80 \%$ for other plastic sheets. The purity of recovered plastics was more than $90 \%$ for polyvinyl chloride, and $70 \%$ for other plastic sheets. The separation performance of a continuous flow apparatus was slightly lower than that of batch operation.
\end{abstract}

Key Words : Plastic Wastes, Plastic Sheets, Triboelectric Separation, Electrified Time, Residence Time.

\section{1. 緒 論}

近年, 広く活用されているプラスチックは自然分解 されることは少なく，また使用量増加により廃棄物と しての処理が追いつかなくなり深刻な社会問題となっ ている。

廃プラスチック問題に対応する一つとして, 廃棄物 を再資源化することが挙げられる。再資源化に対する 処理技術には再生と再利用，燃焼による熱エネルギー の利用などがある。しかし，熱エネルギーに利用する 場合に塩化ビニルなどの塩素を含むプラスチックは有 害物質を発生することや，再利用する場合には付加価 值を高めるために純度が重要であることからプラスチ ックを成分別に分離する必要がある。

前報”でも述べたように，プラスチックに対する 種々な分離方法があるが, 著者らが注目した静電分

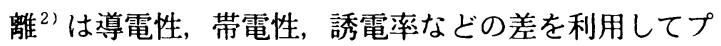
ラスチックの分離を行うもので, 乾式で同一此重のも のでも分離できるという利点がある。近年では，プラ スチックを成分別に分離するために静電分離を利用す

\section{0 年 1 月 6 日受付}

化学工学会第 64 年会（1999年 3 月, 名古屋）にて発表

静岡大学工学部物質工学科化学工学コース

（テ432-8011 浜松市城北 3-5-1） TEL 053-478-1168

Department of Materials Science and Chemical Engineering, Shizuoka University

(3-5-1 Johoku, Hamamatsu-shi, Shizuoka, 432-8011)
る方法として様々な報告がなされているが，前報で紹 介したもの以外をここに記述する。

Yanar ら`はサイクロンを利用した摩擦帯電型の 静電分離装置によるポリ塩化ビニル (PVC) とポリエ チレン（PE）の分離を行い，PEについては良い結果 を得ている。井上ら ${ }^{4)}$ は混合プラスチックから PVC を分離する静電的手法として 4 方式を比較検討してお り, PVC の分離法としては摩擦帯電を利用した静電 誘導型電界分離方式がもっとも有効であることを報告 している。しかし，シート状のプラスチックに関する 研究はほとんど見られない。これは，プラスチック シートが偏平で質量に対する表面積が大きいため帯電 量も大きく，その挙動が不規則なためである。

著者らはシート状プラスチック粒子を成分別に分離 回収するために, 流動層と平行電極を利用した摩擦 帯電型の静電分離装置を試作し，回分式について前 報1.5) で報告したが，本報告ではPVCの分離に対す る連続式について記述する。なお，原理については前 報で述べたので省略する。

\section{2. 試料の物性および実験条件}

実験に使用した被分離プラスチックシートはPVC (ポリ塩化ビニル), PET (ポリエチレンテレフタレー ト), PE (ポリエチレン), PP (ポリプロピレン)の 4 種類, 流動媒体はPVC の 1 種類である。プラスチッ クシートの比重及び厚さを Table 1 に示す。これらは 
Table 1 Characteristics of sheet particles

\begin{tabular}{l|c|c}
\hline \multicolumn{1}{c|}{ Plastic sheet } & Specific gravity $(-)$ & Thickness $(\mu \mathrm{m})$ \\
\hline PVC & 1.41 & 40 \\
\hline PET & 1.38 & 23 \\
\hline PE (black) & 0.95 & 20 \\
\hline PE (transparence) & 0.95 & 29 \\
\hline PP & 0.91 & 29 \\
\hline
\end{tabular}

\begin{tabular}{l|l}
\hline \multicolumn{1}{c|}{ Materials } & $+\leftarrow$ Triboelectric position $\rightarrow-$ \\
\hline PP sheet & $\square$ \\
PE sheet (transparence) & \\
PS particle & \\
PE sheet (black) & \\
PE particle & \\
PET sheet & \\
PVC particle & \\
PVC sheet & \\
\hline
\end{tabular}

Fig. 1 Triboelectric series of plastics $\left(20^{\circ} \mathrm{C}, 40 \%\right)$

製品として市販されているもので，実験には $10 \mathrm{~mm}$ 四方の正方形のものを使用し, 飛散速度 ${ }^{1)}$ は $0.7 \sim 1.0$ $\mathrm{m} / \mathrm{s}$ である。不純物を含まないバージンプラスチッ クを粉砕によって作った PVC 流動媒体粒子は篩径 $1.0 \sim 1.7 \mathrm{~mm}$ であり, 流動化開始速度は $0.37 \mathrm{~m} / \mathrm{s}$ で ある。

実験に使用した被分離シート状粒子と流動体の帯電

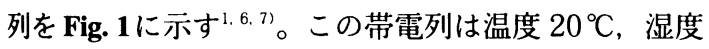
$40 \%$ におけるものであり, PVC シート状粒子と他の プラスチック粒子を分離するためには, PVC 流動媒 体粒子を使えばいいことが分かる。また, 帯電列の順 位は温度や湿度などの外的な条件によって変化するた め，湿度及び温度は常に一定に調整する必要がある。 湿度が高いときには帯電した電荷を放電してしまうた め, 湿度は低いことが望ましいが, 低湿度に調整す ることは実際には困難であり，また湿度が低いとき には流動層塔へのシート状粒子の付着が起きやすく なる。そこで，帯電列を調べた時と同じ条件で，温度 は $20 \pm 1{ }^{\circ} \mathrm{C}$, 湿度は $40 \pm 3 \%$ に調整して実験を行っ ている。本報告では，前報告" ${ }^{1}$ より後に得られた回分 式による高効率のデー夕 ${ }^{5)}$ ，すなわち，シート粒子径 $10 \mathrm{~mm}$, 帯電時間 30 秒, 電界強さ $67 \mathrm{kV} / \mathrm{m}$, シート 充填量 $0.94 \mathrm{~cm}^{2} / \mathrm{cm}^{3}$ を参考にした。

\section{3．実験装置及び方法}

\section{1 予備実験}

流動状態が良好で流動媒体の平均滞留時間8) がほほ

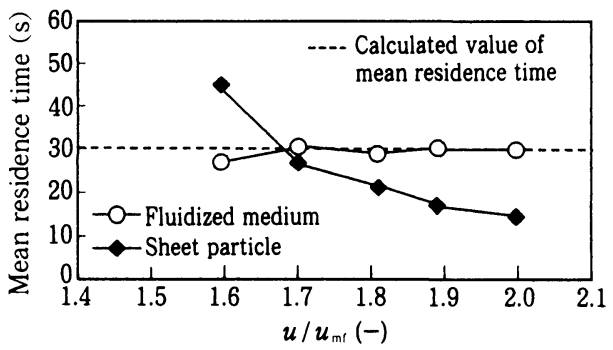

Fig. 2 Relationship between mean residence time and $u / u_{\mathrm{mf}}$

30 秒になる帯電流動層の形状を予備実験より求めた 結果, 縦 $40 \mathrm{~mm}$, 横 $80 \mathrm{~mm}$, 流動層高さ $60 \mathrm{~mm}$ の流 動層を採用した。

シート粒子と流動媒体は流動層内での挙動が異なる ため，その滞留時間も異なると考えられる。シート状 粒子の帯電時間 (平均滞留時間) が 30 秒になる気流 速度を求めるため, 上述した帯電用流動層を用いて気 流速度を $0.59 \sim 0.74 \mathrm{~m} / \mathrm{s}$ まで 5 通りに変化させて, PVC 媒体粒子と PVC シートの滞留時間を測定した。 平均滞留時間の計算值は流動層内粒子質量を粒子供給 量で割って求め, また, 滞留時間は流動状態が安定し た後、ホッパーと接続してある供給シュートにトレ サー粒子あるいはシート粒子を混入させ，流動層に入 ってから出るまでの時間を測定した。

気流速度／流動化開始速度 $\left(u / u_{\mathrm{mf}}\right)$ とシート状粒 子及び流動媒体の平均滞留時間の関係を Fig. 2 に示 す。流動媒体の平均滞留時間は $u / u_{\mathrm{mf}}$ が最も小さい 時には計算值 ${ }^{8)}$ よりも小さくなっているが，これは視 的観察から流動化状態が不均一になることがみられ， 粒子が移動しない部分が生じるためである。 $u / u_{\mathrm{mf}}$ が 1.70 以上の時に, 平均滞留時間は計算值である 30 秒 に近い值になっていて，粒子が均一に混合されてい ることが分かる。一方, シート状粒子の平均滞留時 間は気流速度が大きくなるほど短くなっている。シー 卜状粒子の滞留時間が最も大きい $u / u_{\mathrm{mf}}=1.59$ で は, 流動媒体の流動化状態が悪く，シート状粒子は 


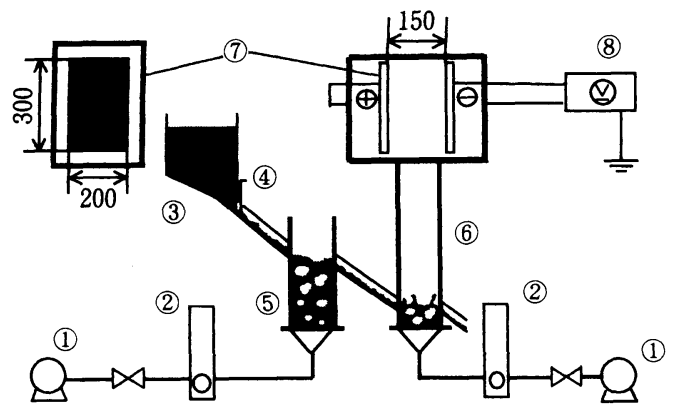

(1) Blower (2) Flowmeter (3) Hopper

(4) Damper (5) Fluidized bed of eletrification

(6) Fluidized bed of separation (7) Electrode

(8) High voltage power pack

Fig. 3 Outline of continuous apparatus with electrostatic separation

粒子層上部に留まっていることが観察された。この ため流動媒体との摩擦も起きにくく，分離を行うの に十分な帯電量が得られていないと考えられる。ま た $u / u_{\mathrm{mf}}=1.86$ 以上の時には，シート状粒子が気流 に吹き上げられ層上部に停滞することが観察され，流 動媒体としての摩擦も起きにくい。これらのことか ら, 流動媒体として PVC 粒子を用いて静電分離を行 うときの気流速度は, シート状粒子と流動媒体との混 合が良好に起こる範囲で帯電時間が 30 秒に最も近い $u / u_{\mathrm{mf}}=1.70$ ，すなわち $0.63 \mathrm{~m} / \mathrm{s}$ 付近が最適と思わ れる。

\section{2 連続実験}

実験装置の概略を Fig. 3 に示す。実験装置は電極部 と流動層部に分けられ, 電極部は $200 \mathrm{~mm} \times 300 \mathrm{~mm}$ の銅製の電極板と電源で構成される。電源で交流電流 を直流に変換し，電極板間に電圧を $0 \sim 30 \mathrm{kV}$ の範囲 で印加する。流動層部はブロワー, 流量メーター, 上 述した寸法の塩化ビニール製帯電用流動層と, 塩化ビ ニール製分離用流動層から構成され，これらをつなぐ 配管は塩ビ管を用いた。なお，配管およびホッパ等は アースを施してある。また，流動層の内壁が摩擦帯電 するとシート状粒子の付着が起きやすくなるため, 内 壁に帯電防止剂を塗布した。

それぞれ除電処理されたシート状粒子（200枚）と 流動媒体 $(300 \mathrm{~g})$ をホッパーに充填した後, 帯電用流 動層へ流入させる。帯電用流動層でシート状粒子は流 動媒体との摩擦により帯電した後溢流し, 分離用流動 層へ流入する。分離用流動層ではシート状粒子は気流 により流動媒体と分離され, 電極部に吹き上げられ, それぞれのシート状粒子は帯電した電荷の極性に応じ

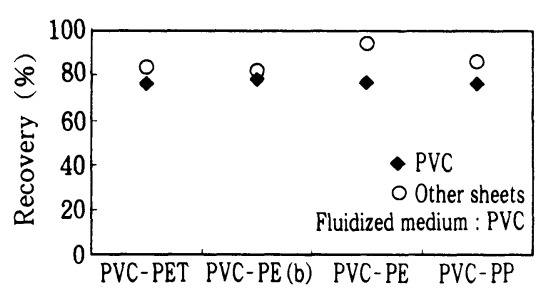

Fig. 4 Relationship between recovery and combination of sheet particles

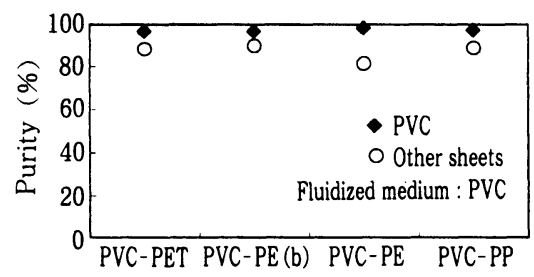

Fig. 5 Relationship between purity and combination of sheet particles

て電極板に引き寄せられ，流動層と電極板の間に落下 し分離される。

流動媒体として PVC 粒子を用い, 被分離シート状 粒子の組合わせはPVC と PET, PE (黒), PE（透 明), PPの 4 通りであり，それぞれの成分について 同数（100枚）のシート状粒子を使用した。シート状 粒子の粒子径は $10 \mathrm{~mm}$ のものを使用し, 帯電用流動 層のシート状粒子充堙量が粒子層 $1 \mathrm{~cm}^{3}$ 当たり 0.94 $\mathrm{cm}^{2}$ 程度 (10mm のシート状粒子では粒子層 $100 \mathrm{~cm}^{3}$ 当たり 90〜100枚）になるようにシート状粒子と流動 媒体を供給した。気流速度は $0.63 \mathrm{~m} / \mathrm{s}$ とし, 分離用 流動層での気流速度は, シート状粒子が瞬時に飛散す るように $2.0 \mathrm{~m} / \mathrm{s}$ とした。各シート状粒子 100 枚に対 して次式で示す各成分の回収率と純度を求めた。

回収率 $=\frac{\text { 目的の電極方向で回収されたシートの枚数 }}{\text { 実験開始時に充塡したシートの枚数 }}$

純 度 $=\frac{\text { 目的とした種類のシートの枚数 }}{\text { ある電極方向で回収されたシートの枚数 }}$

\section{4. 実験結果と考察}

回分式から得られたデータ1.5)を基にして電界強さ を $67 \mathrm{kV} / \mathrm{m}$ とし, 流動媒体として PVC 粒子を用い, 被分離シート状粒子の組合わせを 4 通りに変化させ分 離を行った時の回収率を Fig. 4 に, 純度を Fig. 5 に示 す。いずれの組合わせでも PVC シートでは $75 \%$ 以 上, PVC 以外のシートでは $80 \%$ 以上の回収率が得 られた。この值は前報で得られた回分式での回収率よ 


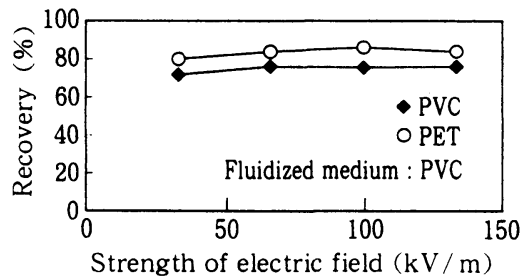

Fig. 6 Relationship between recovery and strength of electric field

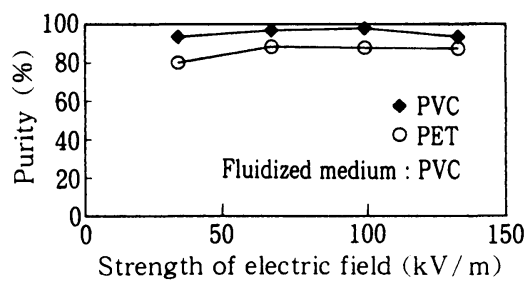

Fig. 7 Relationship between purity and strength of electric field

シートの連続的な成分別分離が可能であると考えられ る。

\section{5. 結 論}

シート状プラスチック粒子を成分別に分離・回収す るために，回分式装置において得られた操作条件を基 に, 流動層と平行電極を利用した摩擦帯電型の連続式 静電分離装置を試作し，シート状プラスチック粒子の 連続的な成分別分離を行った結果, 分離可能であるこ とを確認できたが, 分離性能は回分式装置よりもやや 低下した。流動媒体として PVC 粒子を用いた実験の み行ったが，他の流動媒体を用いても気流速度などの 実験条件次第で分離が可能であると思われる。

この装置では被分離シート状粒子を流動媒体との摩 擦により帯電させているため，被分離シート状粒子同 士の摩擦により帯電させる場合と異なり, 被分離シ一 卜状粒子の混合比による分離性能の変化が少なく，リ サイクルにおける原料混合比の調整は不要であると考 えられる。また，多成分の分離であっても，2段階以 上のプロセスにより可能となると考えられるが，带電 列の順位は温度, 湿度などの外的な条件やプラスチッ クの成因や添加物によって変化するため, これらの条 件を管理する必要はある。

\section{References}

1) Takeshita, T., K. Atsumi, Y. Iwasaki and T. Harada : "The Triboelectric Separation for Plastic Sheets", J. Soc. Powder Technol. Japan, 35, 106-110 (1998)

2 ) Tore R \& D : "Plastic Recycling Gijutu no Shintenkai", p. 47, Tore Research Center (1992)

3 ) Yanar, D. K. and B. A. Kwetkus: "Electrostatic separation of polymer powders", Journal of Electrostatics, 35, 257-266 (1995)

4 ) Inoue, T., T. Tamakoshi, M. Tukahara, H. Arai and H. Maehata : "Development of Plastic Sorting Technology using Electrostatic Separation Method", Preprints of The Institute of Electrostatics, Japan ; 339340 (1996)
5 ) Harada, T., Y. Hiraiwa, S. Takeichi, T. Takeshita and K. Atsumi: "Electrostatic Separation for Plastic Sheet Particles", Preprints of 28th Annual Meeting of Union of Chemistry Related Societies in Chubu Area, Japan, p. 139, Hamamatsu (1997)

6 ) Nakajima, Y. and T. Tanaka : "Triboelectric Separator for Plastics Sorting System”, The Micromeritics, No. 28, 4-13 (1984)

7 ) Nagata, K: “Static Electricity”, p. 6, Baifukan (1987)

8 ) Kunii, D. and O. Levenspiel: "Fluidization Engineering”, p. 73, John Wiley and Sons, Inc., U. S. A., Toppan Company, Limited (1969) 